
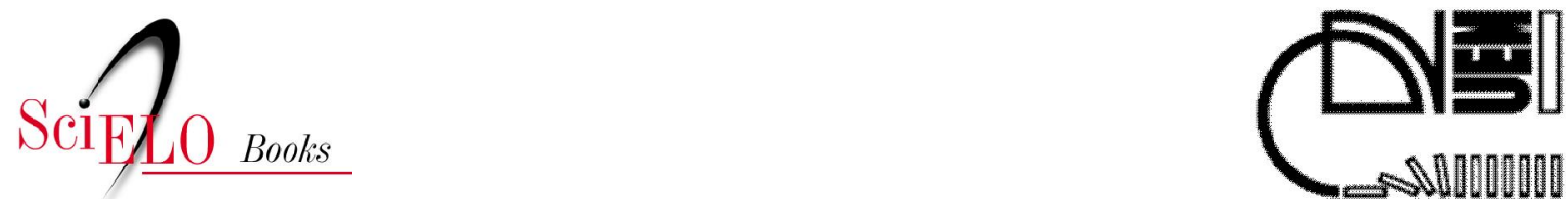

\title{
14 A Ditadura Militar e a violência contra os movimentos sociais, políticos e culturais
}

\author{
Angelo Priori \\ Luciana Regina Pomari \\ Silvia Maria Amâncio \\ Veronica Karina Ipólito
}

SciELO Books / SciELO Livros / SciELO Libros

PRIORI, A., et al. História do Paraná: séculos XIX e XX [online]. Maringá: Eduem, 2012. A Ditadura Militar e a violência contra os movimentos sociais, políticos e culturais. pp. 199-213. ISBN 978-857628-587-8. Available from SciELO Books $<\underline{\text { http://books.scielo.org }>\text {. }}$

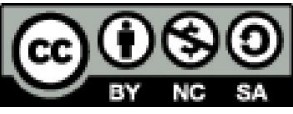

All the contents of this chapter, except where otherwise noted, is licensed under a Creative Commons Attribution-Non Commercial-ShareAlike 3.0 Unported.

Todo o conteúdo deste capítulo, exceto quando houver ressalva, é publicado sob a licença Creative Commons Atribuição Uso Não Comercial - Partilha nos Mesmos Termos 3.0 Não adaptada.

Todo el contenido de este capítulo, excepto donde se indique lo contrario, está bajo licencia de la licencia Creative Commons Reconocimento-NoComercial-CompartirIgual 3.0 Unported. 


\section{4}

\section{A Ditadura Militar e a violência contra os movimentos sociais, políticos e culturais}

\section{A Ditadura Militar}

No Brasil, o fim das liberdades democráticas, a repressão e o terror como política de Estado foram formulados por meio de uma bem arquitetada estrutura legislativa, que dava sustentação ao regime militar. Devemos enfatizar que a ditadura militar não foi resultado do acaso, de um acidente. Pelo contrário, ela foi sendo estruturada conforme a democracia e a participação política da população iam se ampliando. Não podemos negar que no início dos anos 1960 estava sendo configurada uma nova forma de ação, por meio da organização popular, que questionava o arbítrio interno e a dependência externa e exigia mudanças nas estruturas econômicas e sociais, visando a uma maior inclusão social da população pobre e trabalhadora.

O grupo militar que tomou o poder em 1964 vinha de uma tradição militar mais antiga, que remontava à participação do Brasil na II Guerra. A participação do Brasil ao lado dos países aliados acabou sedimentando uma estreita vinculação entre os oficiais norte-americanos e militares 
brasileiros, como os generais Humberto de Castelo Branco e Golbery Couto e Silva.

Terminada a guerra, toda uma geração de militares brasileiros passou a frequentar cursos militares norte-americanos. Quando esses oficiais retornavam dos EUA, já estavam profundamente influenciados por uma concepção de 'defesa nacional' (ALVES, 1987). Tanto que, alguns anos mais tarde, iriam criar a Escola Superior de Guerra (ESG), vinculada ao Estado Maior das Forças Armadas. Essa escola foi estruturada conforme sua similar norte-americana, National War College (HUGGINS, 1998).

Foi dentro da ESG que se formularam os princípios da Doutrina de Segurança Nacional e alguns dos seus subprodutos, como, por exemplo, o Serviço Nacional de Informações (SNI). Essa doutrina transformou-se em lei no ano de 1968, com a publicação do decreto-lei no. 314/68, que tinha como objetivos principais identificar e eliminar os 'inimigos internos', ou seja, todos aqueles que questionavam e criticavam o regime estabelecido. E é bom que se diga que 'inimigo interno’ era, antes de tudo, comunista. Como diz Nelson Werneck Sodré: “'o anticomunismo, foi assim e, sempre, o caminho para a ditadura” (1984, p. 91).

Essa nova estrutura de poder e de controle social se materializou com a publicação do Ato Institucional No. 1, que subverteu a ordem jurídica até então estabelecida. No preâmbulo do AI-1, instituído em 09 de abril de 1964, os militares já enfatizavam essa nova realidade.

$\mathrm{O}$ ato institucional que é hoje editado se destina a assegurar ao novo governo a ser instituído os meios indispensáveis à ordem de reconstrução econômica, financeira, política e moral do Brasil, de maneira a poder enfrentar de modo direto e imediato os graves e urgentes problemas de que dependem a restauração da ordem interna e o prestígio internacional de nossa pátria (HELLER, 1988, p. 627).

Com esse ato, os militares não só ditavam novas regras constitucionais, como impunham profundas remodelações no sistema de 200 segurança do Estado. Por meio do AI-1, foi institucionalizado o sistema 
de eleição indireta para Presidente da República, bem como foi dado poderes ao presidente para ditar nova constituição, fechar o congresso, decretar estado de sítio, impor investigação sumária aos funcionários públicos contratados ou eleitos, abrir inquéritos e processos para apurar responsabilidades pela prática de crime contra o Estado ou contra a ordem política e social, suspender direitos políticos de cidadãos pelo prazo de dez anos e cassar mandatos legislativos de deputados federais, estaduais ou vereadores.

Durante a ditadura militar foram editados 17 atos institucionais. Mas, entre eles, o mais polêmico e violento foi o de Número 5. O AI-5, editado em 13 de dezembro de 1968, re-editou os princípios do AI-1, suspendeu o princípio do babeas corpus e instituiu, de forma clara e objetiva, a tortura e a violência física contra os opositores do regime.

$\mathrm{Na}$ verdade o AI-5 simbolizou um terceiro ciclo de repressão. O primeiro ciclo foi originado em meio à turbulência do golpe de 1964 e teve, como base, principalmente, a retirada do âmbito político de pessoas vinculadas ao governo deposto de João Goulart. Fisicamente, a repressão recaía apenas sobre os trabalhadores e camponeses que, aos olhos dos militares, poderiam acabar desenvolvendo um foco de combate e resistência contra o governo oficial. O segundo ciclo (1965-1966) desmontou o aparelho democrático do Estado, como as eleições diretas, o pluripartidarismo e a existência de organizações sociais livres. Finalmente, o terceiro ciclo realizou

\footnotetext{
amplos expurgos em órgãos políticos representativos, universidades, redes de informação e no aparato burocrático do Estado, acompanhados de manobras militares em larga escala, com indiscriminado emprego da violência contra todas as classes (ALVES, 1987, p. 141).
}

O manto dos atos institucionais e a autoridade absoluta dos militares serviriam como proteção e salvaguarda do trabalho das forças repressivas, fossem quais fossem seus métodos de ação. Só para termos uma 
ideia, durante o regime militar foram criados vários órgãos de repressão, como o SNI, os DOI-CODI, o CIEX, o CENIMAR, a CISA, além do fortalecimento dos DOPS em todos os Estados. Foram criados ainda os Inquéritos Policiais Militares (IPM), cujos objetivos eram processar e criminalizar militantes e políticos que lutavam contra o regime militar. Somente o projeto Brasil: Nunca Mais (BNM) conseguiu reunir cópias de 717 IPM, em que foram processadas mais de 20 mil pessoas (ARNS, 1985). Muitos dos processos não vieram à tona e estão ainda por ser verificados. Esperamos que, com a Comissão da Verdade, que em 2012 irá se instalar, outros documentos surjam para o conhecimento da sociedade brasileira.

Uma das reflexões possíveis, que tange à especificidade do governo militar brasileiro, refere-se à forma como o regime autoritário foi arquitetado no país. O regime foi articulado por uma notável ambiguidade, pois, mesmo no exercício de um regime de exceção e essencialmente enfatizado por uma indelével 'lógica da suspeição', os dirigentes procuravam legitimálo e caracterizá-lo como um sistema de governo democrático. Do primeiro general-presidente (Humberto de Alencar Castello Branco) até o último (João Baptista de Oliveira Figueiredo) foi salientada, principalmente, nos discursos de posse dirigidos ao povo brasileiro, a adoção de "ações e comportamentos em nome da defesa da democracia no país" (AQUINO, 2000, p. 272).

Por outro lado, constatou-se, ao longo de 21 anos de permanência dos militares no poder, que a existência de uma administração democrática foi apenas fictícia, haja vista o contundente papel repressor desempenhado pelos órgãos policiais e jurídicos a fim de suplantar possíveis distúrbios sociais que afetassem o andamento das atividades do Poder Executivo.

Em princípio, o golpe militar foi visto como um "movimento fadado a ser de curta duração e de alcance limitado" (CARONE, 1982, p. 3). No entanto, com o decorrer dos primeiros dias, o comando militar se estruturava sobre pilares do autoritarismo e autonomeava-se salvador da democracia. O golpe se caracterizava como uma intervenção corretiva que se destinava a preservar valores democráticos. No entanto, essa 
aparência democrática era apenas teórica. Na prática, diversos brasileiros, inclusive, ex-presidentes, como Jânio Quadros e Juscelino Kubitschek, parlamentares, jornalistas, intelectuais, sindicalistas, tiveram seus direitos políticos cassados. As punições foram as mais variadas e regulamentadas pelo combate à subversão e à corrupção.

O governo de Emílio Garrastazu Médici (1969-1974) representou o período de maior repressão, de arbitrariedade e de prepotência de todo o ciclo militar (GASPARI, 2002). Por outro lado, o 'milagre econômico', que se processou entre os anos de 1968 e 1973, estigmatizado, principalmente, pelos grandiosos projetos públicos e pelo acelerado crescimento econômico, diminuiu o impacto causado pelas medidas de segurança utilizadas pelo governo. Além do que, pela ação de um marketing eficiente e uma censura forte, criou-se um clima de ufanismo em toda a nação, contribuindo, em grande medida, para o fortalecimento da imagem do presidente que angariou grande margem de prestígio, principalmente nas camadas populares.

Foi no governo de Médici e, com menor ênfase no governo do General Ernesto Geisel (1974-1979), que os grupos identificados com as guerrilhas urbana e rural foram sendo progressivamente eliminados. A repressão desencadeada na época atingiu centenas, talvez milhares de pessoas envolvidas com a luta armada. O projeto da Arquidiocese de São Paulo, conhecido como Brasil: nunca mais, conseguiu mapear, durante a ditadura militar, 125 pessoas desaparecidas e quase 300 que foram assassinadas (ARNS, 1985).

\section{Violência e resistência}

Mesmo como uma política econômica e com um forte aparato de repressão, sustentadas por Atos Institucionais e pela Lei de Segurança Nacional, os movimentos sociais e políticos conseguiram criar uma rede de protesto e de resistência que colocavam em xeque as medidas adotadas 
pelos militares. Mesmo dentro das classes dominantes, foram sendo verificados descontentamentos. É o caso de Carlos Lacerda, Juscelino Kubitschek e João Goulart, que, com outros civis, formularam a 'Frente Ampla' de oposição, em 1969. Apesar de vida efêmera, a 'Frente Ampla' elaborou um programa político que exigia anistia geral, promulgação de uma constituição democrática e restabelecimento das eleições diretas em todos os níveis. Não foi por acaso que Lacerda, JK e Goulart morreram de maneira ainda inexplicáveis. Isso mostrava, de certa forma, que nem tudo caminhava como a ditadura queria, isto é, alguns grupos não estavam se incorporando às novas estruturas de poder e, portanto, a ditadura não tinha uma legitimação consensual, pelo menos entre as classes dominantes, como ela imaginava ter conquistado.

Mas o maior desafio que a ditadura encontrou foi a resistência da esquerda e dos movimentos sociais. O primeiro movimento que se articulou contra a ditadura militar foi liderado pelo Ex-coronel Jefferson Cardim de Alencar Osório. No mês de março de 1965, uma coluna com 30 homens partiu do Uruguai e invadiu o Estado do Rio Grande do Sul, ganhando o apoio de Leonel Brizola e de outros políticos da região. A tentativa do coronel era desencadear uma revolução, a partir dos Estados do Sul e derrubar o regime militar. A coluna guerrilheira participou de três ou quatro ações, nos Estados do Rio Grande do Sul e Santa Catarina, mas, quando já adentrava ao Estado do Paraná, os rebeldes foram presos, e o seu líder foi enviado para Curitiba, onde foi condenado (HELLER, 1988).

Depois disso, outras tentativas de guerrilha contra a ditadura foram sendo formuladas. Destaca-se a guerrilha do Caparaó, articulada pelo Movimento Nacionalista Revolucionário (MNR), que escolheu a serra do Caparaó, na divisa dos Estados de Minas Gerais e Espírito Santo, para fazer treinamentos dos guerrilheiros. Os guerrilheiros de Caparaó, que teriam a missão de criar 'insegurança permanente' à ditadura militar, pretendiam tomar cidades, destruir linhas de comunicações, vias de transportes e atacar pelotões do Exército, visando chamar a atenção do país para o que estava acontecendo e fazer a exortação da luta armada. No entanto, os planos 
audaciosos da guerrilha foram debelados bem antes de os guerrilheiros começarem as suas ações. Em abril de 1967, 16 guerrilheiros foram presos e condenados com pena de quatro a 12 anos de detenção.

Foi no campo também que ocorreu a maior resistência armada contra a ditadura militar. Trata-se da guerrilha do Araguaia, organizada pelo Partido Comunista do Brasil (PCdoB) na região conhecida como bico do papagaio, atual Estado de Tocantins.

\begin{abstract}
Nessa região, no ano de 1966, começaram a se desenvolver grandes projetos agropecuários, subsidiados pela Sudam (Superintendência do Desenvolvimento da Amazônia). As multinacionais, com o beneplácito do governo, saciavam seus apetites explorando amplas regiões de nosso território. Dia a dia, acelerava-se o processo de internacionalização da economia brasileira (MOCELLIN, 1989, p. 43).
\end{abstract}

Paralelamente à divisão do território nacional entre as multinacionais, processava-se a expansão do latifúndio com a expulsão dos posseiros da região, que muitas vezes sofriam perseguições violentas ou eram assassinados pelos capangas a serviço das classes dominantes. Foi, portanto, diante dessa situação social existente na região, que o PCdoB, a maioria jovens universitários advindos das cidades e da classe média e sem nenhuma experiência militar, começaram a chegar à região em 1967, quando começaram a fazer treinamento militar, cursos de sobrevivência na selva, de primeiros socorros, além de trabalhar na roça e compartilhar dos problemas da população local, visando conhecer a cultura e a realidade daquela gente (MOURA, 1985).

Durante sete anos, a guerrilha se manteve na região. No entanto, os grupos armados não passavam de 70 pessoas, mas mobilizaram grande efetivo do Exército brasileiro. Quando os militares descobriram que no Araguaia havia a existência de militantes políticos fazendo treinamento de guerrilha, trataram logo de deslocar alguns destacamentos para a região para combater os chamados 'terroristas'. Em outubro de 1973, o Exército, com um efetivo de 6.000 homens, aviões, helicópteros, paraquedistas e 
homens bem treinados em combates na selva, tomou a região, que foi atacada na forma de arco, para impedir a fuga dos guerrilheiros. Para garantir o sucesso da operação, foram estabelecidas bases de apoio em fazendas, roças e castanhais. A população local passou a ser tratada com extrema violência e a tortura tornou-se rotina naquele rincão sertanejo. No Natal de 1973, o Exército desbaratou a comissão militar da guerrilha, que dirigia a luta dentro da selva. Os militantes passaram a ser localizados e assassinados com maior rapidez. A situação começou a ficar insustentável. Em maio de 1974, o comitê central do PCdoB deu ordens para que a guerrilha fosse dispersada. Mas era tarde demais. Aproximadamente 70 militantes haviam sido mortos pela ditadura. Poucos lograram escapar; pouquíssimos sobreviveram.

Mas a luta contra a ditadura não ocorreu apenas no campo. Nas cidades, muitas organizações de esquerda atuaram e lutaram de armas na mão. Entre as que mais se destacaram, estão a Ação Libertadora Nacional (ALN), liderada por Carlos Marighela; o Partido Comunista Brasileiro Revolucionário (PCBR), cuja direção máxima estava a cargo do jornalista e intelectual, Mário Alves; O Movimento Revolucionário 08 de outubro (MR-8); a Política Operária (Polop); e, depois, a Vanguarda Popular Revolucionária (VPR), comandada pelo ex-capitão do Exército, Carlos Lamarca, entre várias outras organizações menores como PCR, Molipo, MRT, PRT, Colina, etc. (GORENDER, 1987; REIS FILHO, 1990).

A Aliança Libertadora Nacional foi a organização que melhor formulou as estratégias de luta armada na cidade. Surgida de uma dissidência do Partido Comunista Brasileiro (PCB), no ano de 1967, tinha como líder máximo, Carlos Marighela, militante e intelectual comunista com grande experiência organizativa e conhecedor dos movimentos sociais. Marighela tinha sido deputado constituinte em 1946 pelo PCB e uma das maiores lideranças daquele partido. Após o golpe militar de 1964, começou a divergir com o 'partidão', principalmente no que tangia ao encaminhamento das estratégias de resistência. Enquanto o PCB optava pela luta pacífica de combate à ditadura militar, Marighela definia- 
se pela luta armada (GORENDER, 1987; VINHAS, 1982). Em 1967, desligou-se da Comissão Executiva do PCB e em seguida viajou para Havana, onde participou da assembleia da Organização Latino-americana de Solidariedade (OLAS), evento em que foi formulado um pretensioso plano de luta que objetivava desencadear ações revolucionárias em toda a América Latina. Quando do seu regresso ao Brasil, foi expulso do PCB. Fundou então a ALN.

A ALN propunha a guerrilha urbana, visando conseguir recursos para elaborar uma bem estruturada organização e, depois, desencadear a guerrilha rural. Marighela dizia:

Da área urbana passaremos à luta armada, direta, contra os latifundiários, através da guerrilha rural. Da aliança armada de operários e camponeses com estudantes, através da guerrilha móvel no campo, cruzando o interior do Brasil em todas as direções, chegaremos ao exército revolucionário de libertação nacional e ao confronto com o exército convencional da ditadura militar (ARQUIVO DOPS, pasta 25, cx. 4).

O líder da ALN não teve tempo de levar adiante o seu ideal. Foi assassinado pela ditadura militar, na cidade de São Paulo, em uma emboscada preparada pelo Delegado Sérgio Paranhos Fleury, da Delegacia de Ordem Política e Social (DOPS), no dia 04 de setembro de 1969.

Embora as ações das organizações da luta armada tenham colocado em xeque a ditadura militar, foram as grandes mobilizações de massas que preocupavam os militares. Pois, contra os guerrilheiros, que agiam de forma violenta, causando certo impacto contra a sociedade, os militares tinham um discurso e até uma justificativa para a prática da repressão. Eles diziam que os guerrilheiros eram 'terroristas', que queriam implantar um regime comunista no país, que eram contra a liberdade, as leis, a família, a propriedade, etc. No entanto, quando usavam de extrema violência contra manifestações pacíficas, desnudava-se a face mais cruel e violenta da ditadura. 
Numa época em que os partidos políticos de esquerda estavam proscritos, os sindicatos estavam sofrendo uma forte intervenção estatal e os movimentos sociais, como um todo, eram vigiados e controlados pelos órgãos de repressão, foram os estudantes que mais se destacaram na luta contra a ditadura. O movimento estudantil funcionou, de certa forma, como um porta-voz da sociedade contra o regime militar.

Os estudantes tiveram vida ativa durante todo o regime militar. Já em 1965, foi realizado um plebiscito, nas escolas do Rio de Janeiro, que repudiava a tentativa do ministro da educação, Flávio Suplicy de Lacerda, de extinguir a União Nacional dos Estudantes (UNE) e substituí-la por um Diretório Nacional dos Estudantes, atrelado aos militares. Em 1966, a UNE realizou o seu $28^{\circ}$ congresso nacional, em Belo Horizonte. No mês de setembro desse ano, ainda, foram realizadas grandes passeatas em São Paulo, Belo Horizonte, Porto Alegre, Rio de Janeiro, Brasília e Curitiba, quando os estudantes reivindicavam ensino gratuito, autonomia universitária, não vinculação da universidade com órgãos americanos (USAID), além da defesa da UNE e do fim da ditadura militar (MARTINS FILHO, 1997).

Mas nada foi tão significativo como o ano de 1968. Aproveitando a onda de grandes manifestações estudantis que aconteciam na Europa, sobretudo em Paris e em Praga, os estudantes brasileiros saíram às ruas para protestar contra a ditadura militar, pelo fim do convênio MEC/USAID e pelo ensino gratuito. Em 28 de março de 1968 foi morto pela ditadura, no Rio de Janeiro, o estudante Edson Luís Lima Souto, quando participava de uma manifestação pacífica em defesa do restaurante universitário 'calabouço'.

Esse incidente desencadeou um protesto nacional contra a violência da ditadura, cujo epicentro foi a cidade do Rio de Janeiro. Em uma semana, houve pelo menos 26 grandes passeatas em 15 capitais de estados (MARTINS FILHO, 1997, p. 18). 
A onda de passeatas teve seu auge no dia 26 de junho de 1968, quando uma passeata reuniu 100 mil pessoas no Rio de Janeiro. No mês de junho ocorreram outras 16 passeatas em vários Estados do país.

Após 1968, por quase dez anos, o movimento estudantil passou por um refluxo. Foram os anos em que os grupos guerrilheiros se proliferaram. Aliás, grande parte deles foi recrutada no meio estudantil (RIDENTI, 1993). Em 1977, a agitação estudantil eclodiu novamente, tendo como bandeira as lutas pelo fim da ditadura militar, as campanhas pela libertação de estudantes presos, as campanhas pelo fim das torturas e os vários protestos contra administrações universitárias autoritárias. Essas lutas do final dos anos 1970 motivaram a reconstrução da UNE em 1979.

$\mathrm{Na}$ área intelectual também eram visíveis as manifestações críticas contra o governo militar. Destacam-se as músicas de protesto de Chico Buarque, Taiguara, Geraldo Vandré, Caetano Veloso, Gilberto Gil, Capinam, Torquato Neto, entre outros. Mas foi a voz de uma mulher que imortalizou a canção de João Bosco e Aldir Blanco, O bêbado e o equilibrista, consagrada como o hino da anistia aos banidos e exilados políticos do país. A voz emocionada de Elis Regina entoava com beleza singular os versos de Aldir Blanco sobre assassinatos nos porões da ditadura, de maridos pranteados por "Marias e Clarices" e sobre a luta pela anistia aos desaparecidos, presos e exilados políticos, ao pedir a volta do "irmão do Henfil e tanta gente que partiu num rabo de Foguete".

No cinema se destacaram alguns cineastas que fizeram produções engajadas e de resistência. Filme como Os fuzis, de Rui Guerra, Deus e o diabo na Terra do Sol, de Glauber Rocha (REIS FILHO, 2001), ou mesmo produções que tiveram maior alcance popular, como O Rei da Noite, Xica da Silva, Lúcio Flávio, Pixote, Bye bye Brasil, O homem que virou suco, etc., procuravam mostrar a dura realidade em que vivia o povo brasileiro.

$\mathrm{Na}$ estratégia de repressão contra os movimentos sociais, foi o movimento sindical que mais sofreu com a ditadura militar. A fala do operário metalúrgico Diogo Afonso Gimenez retrata fielmente a questão: 
Foi um golpe de classe contra os trabalhadores, e já em abril de 1964 houve intervenção em centenas de sindicatos e a prisão de seus dirigentes. Uma exigência das multinacionais, do capital estrangeiro e dos seus aliados aqui dentro, que queriam a todo custo reduzir o ímpeto das reivindicações operárias. Mataram, prenderam e torturaram centenas de líderes sindicais. Acabaram com a estabilidade no emprego, substituindo-a pelo Fundo de Garantia por Tempo de Serviço, e começaram a arrochar os salários. Os que protestavam eram presos ou desapareciam (HELLER, 1988, p. 158).

A partir do golpe, os trabalhadores foram sendo sistematicamente esmagados, marginalizados. Por um longo período, o sindicalismo mais combativo foi incapaz de se organizar na ilegalidade. Ampliava-se, com a ajuda do Estado, o sindicalismo do 'sim senhor', que desenvolvia uma prática assistencialista, sem contestar o status quo estabelecido e o autoritarismo da ditadura militar.

Os movimentos sindical e estudantil estão enfraquecidos, contidos pela repressão, emudecidos pela censura e ofuscados pela euforia econômica. Praticamente não há passeatas, comícios, agitação de rua nem greve. As forças de segurança, militares e policiais, com ampla liberdade de ação e, muitas vezes, com exageros típicos da arbitrariedade ditatorial, como prisões descabidas, torturas, seqüestros e mortes, combatem e vencem a esquerda armada (COUTO, 1999, p. 111).

Foi somente a partir do final da década de 1970, quando a inflação no país já estava incontrolável, os salários estavam cada vez mais arrochados, a concentração de renda era cada vez mais visível e a ditadura dava sinais claros de enfraquecimento, que o movimento sindical retornou suas atividades com maior força. As greves operárias no ABC paulista, nos anos 1978/80, o nascimento das centrais sindicais, notadamente da CUT, em 1983, e o fim da ditadura militar em 1985 deram novo alento ao movimento sindical, embora já sem a força que o caracterizara durante todo o início e meados do século XX. 
Não poderíamos deixar de concluir este capítulo sem analisar a participação das mulheres contra a ditadura militar. A forma de resistência das mulheres foi construída desde o mundo estritamente privado, quando o chefe da família (marido, pai, irmão) perdia o seu emprego, era preso, assassinado ou 'desaparecido' político, até as atuações de defesa da dignidade nacional, tradições e valores públicos. As mulheres foram capazes de demonstrar que entendiam de política ao lutarem contra a desagregação moral da unidade familiar impostas pelos regimes autoritários que tentavam desmoralizar os sentimentos mais profundos das mulheres como mães, esposas, irmãs e filhas.

O autoritarismo e a repressão serviram para que muitas mulheres desenvolvessem sua inteligência, criatividade e capacidade política como num jogo dialético. As mulheres resistiram ao autoritarismo não apenas dentro de casa, ou descobrindo formas diferentes de enfrentar a clandestinidade quando os partidos progressistas foram proibidos, mas também no exílio, pois milhares de mulheres tiveram que deixar seu país para continuarem vivas.

O exílio era um dos graves problemas da conjuntura internacional nas décadas de 1960 e 1970, e era mais grave ainda para a grande parcela de mulheres que tiveram que exercer as tarefas de mães em situações difíceis. A amarga experiência do exílio marcou profundamente a estrutura familiar e, também, cada um dos membros da família, além disso, a grande trauma de não poder viver na própria pátria foi extremamente angustiante e desterritorializante (COSTA et al., 1980; ROLLEMBERG, 1999; POMARI, 2002).

O papel ativo das mulheres na luta contra a ditadura militar teve vários fronts: na reorganização do movimento sindical, na re-estruturação das organizações políticas de esquerda, na distribuição de ajuda da solidariedade internacional e nas campanhas pela libertação dos presos políticos.

O compromisso das mulheres com as lutas democráticas não implicou, necessariamente, que estivessem em jogo os interesses e 
direitos das mulheres, prioritariamente. O compromisso político da maioria delas não provinha de conhecimentos ideológicos democráticos ou de cálculos de estratégias antiditatoriais, pois não havia uma lógica política, mas sim uma lógica do afeto (POMARI, 2002). Porque as mulheres foram diretamente afetadas como mães, avós e familiares de vítimas políticas. No primeiro momento o pessoal estava acima do público ou do político. Não era heroísmo que mobilizava essas mulheres, mas sim uma visão dilatada do seu papel feminino de cuidar da família com amor e dedicação.

Necessariamente é difícil esperar que as militantes expressassem de forma espontânea reivindicações intrínsecas às mulheres, pois, quando essas reivindicações se constituíram em exigência programática, houve entraves no diálogo com o feminismo. Por isso, é ainda um desafio poder transformar a sensibilidade social criada por esses movimentos de resistência em estratégias que possam reverter formas de subordinações e marginalizações, nos diferentes âmbitos da vida cotidiana das mulheres.

\section{Referências}

ALVES, M. H. M. Estado e oposição no Brasil (1964-1984). Petrópolis: Vozes, 1987.

AQUINO, M. A. A especificidade do regime militar brasileiro: abordagem teórica e exercício empírico. In: REIS FILHO, D. A. (Org.). Intelectuais, história e política (séculos XIX e XX). Rio de Janeiro: 7 Letras, 2000. p. 271-287.

ARNS, P. E. Brasil: nunca mais - um relato para a história. Petrópolis: Vozes, 1985.

ARQUIVO DOPS/PR. Aliança Libertadora Nacional, pasta 25, cx. 4, 1969.

CARONE, E. O PCB (1964-1982). São Paulo: Difel, 1982. v. 3.

COSTA, A. C. et al. Memórias das mulheres no exílio. Rio de Janeiro: Paz e Terra, 1980.

COUTO, R. C. História indiscreta da ditadura e da abertura - Brasil: 1964-1985. 3. ed. Rio de Janeiro: Record, 1999.

GASPARI, E. A ditadura escancarada. São Paulo: Cia das Letras, 2002.

GORENDER, J. Combate nas trevas. São Paulo: Ática, 1987. 
HELLER, M. I. Resistência democrática: a repressão no Paraná. Rio de Janeiro: Paz e Terra, 1988.

HUGGINS, M. K. Policia e politica: relações Estados Unidos/América Latina. São Paulo: Cortez, 1998.

MARTINS FILHO, J. R. O movimento estudantil na conjuntura do golpe. In: TOLEDO, C. N. (Org.). 1964: visões críticas do golpe. Campinas: Unicamp, 1997. p. $12-21$.

MOCELLIN, R. As reações armadas ao regime de 64. Guerrilha ou terror? São Paulo: Editora do Brasil, 1989.

MOURA, C. Diário da guerrilha do Araguaia. São Paulo: Alfa-Ômega, 1985.

POMARI, Luciana. Uma revolução para Penélope: a cultura do exílio, a militância feminina e a construção de uma história de lutas, no Brasil e no exterior (1964-1984). 2002. 330 f. Tese (Doutorado em História) - UNESP, Assis, 2002.

REIS FILHO, D. A. A revolução faltou ao encontro: comunistas no Brasil. 2. ed. São Paulo: Brasiliense, 1990.

REIS FILHO, D. A. Ditadura militar, esquerdas e sociedade. Rio de Janeiro: Zahar, 2001.

RIDENTE, M. O fantasma da revolução brasileira. São Paulo: Edunesp, 1993.

ROLLEMBERG, D. Exílio: entre raízes e radares. Rio de Janeiro: Record, 1999.

SODRÉ, N. W. Vida e morte da ditadura: 20 anos de autoritarismo no Brasil. Petrópolis: Vozes, 1984.

VINHAS, M. O partidão: a luta por um partido de massas (1922-1974). São Paulo: Hucitec, 1982. 